\title{
A perindopril/amlodipin szabad és fix kombinációk egyéves terápiahüsége
}

\author{
Simonyi Gábor dr. ${ }^{1}$ - Ferenci Tamás $d r^{2}{ }^{2}$ Medvegy Mihály dr. ${ }^{3}$ \\ Gasparics Roland dr. ${ }^{1}$ - Finta Ervin dr. ${ }^{4}$ \\ ${ }^{1}$ Szent Imre Egyetemi Oktatókórház, Anyagcsere Központ, Budapest \\ ${ }^{2}$ Óbudai Egyetem, Neumann János Informatikai Kar, Élettani Szabályozások Csoport, Budapest \\ ${ }^{3}$ Pest Megyei Flór Ferenc Kórház, III. Belgyógyászat-Kardiológiai Osztály, Kistarcsa \\ ${ }^{4}$ Szent Imre Egyetemi Oktatókórház, Kiemelt Hotelszolgálat I. Anyagcsere Központ, Budapest
}

\begin{abstract}
Bevezetés: A hypertonia kezelése során a terápiahűség az egyik legfontosabb tényező, mivel a cardiovascularis kockázatcsökkentés eléréséhez folyamatos gyógyszerelésre van szükség.

Célkitüzés: A szerzők célja a hypertonia indikációban indított perindopril/amlodipin szabad és fix kombinációk egyéves perzisztenciájának összehasonlítása volt.

Módszer: A szerzốk az Országos Egészségbiztosítási Pénztár adatbázisából, a vényforgalmi adatokra támaszkodva, hypertonia indikációban, 2012. október 1. és 2013. szeptember 30. között elsố alkalommal a perindopril/amlodipin szabad és fix kombinációinak receptjeit kiváltó olyan betegeket választottak ki, akik a megelőző egy évben hasonló hatóanyagokkal nem részesültek antihipertenzív terápiában. A perzisztencia modellezésére a túlélésanalízis klasszikus eszköztárát alkalmazták, ahol a „túlélési” idő a gyógyszer szedésének abbahagyásáig eltelt idő volt. A modellezéshez komplementer log-log link függvényt használó általánosított lineáris modellt becsültek, mint diszkrét túléléselemzési modell.

Eredmények: A bevonási kritériumoknak 109248 beteg felelt meg. Ebből a fenti időszakban 19365 beteg kezdett perindopril és amlodipin szabad, míg 89883 beteg perindopril és amlodipin fix kombinációval antihipertenzív terápiát. A megfigyelt időszakban a perindopril/amlodipin szabad kombinációjának egyéves perzisztenciája 27,15\%, míg a fix kombinációé 46,89\% volt. A 360 napra korlátozott átlagos perzisztencia időtartama 177,6 nap volt a szabad, míg 245,7 nap volt a fix kombinációt szedő csoportban. A szabad és a fix kombinációs kezelést vizsgálva azt találták, hogy a szabad kombináció esetén mintegy kétszeres a gyógyszerelhagyás pillanatnyi rátája a fix kombinációhoz képest (kockázatarány = 1,94 [95\% CI: 1,91-1,98], p<0,001).

Következtetések: A szerzők igazolták, hogy a hypertonia indikációban alkalmazott perindopril/amlodipin szabad és fix kombinációs terápia közül - a betegadherencia szempontjából - a fix kombinációs készítmény bizonyult egyértelmüen elönyösebbnek.

Orv Hetil. 2017; 158(36): 1421-1425.
\end{abstract}

Kulcsszavak: adherencia, perzisztencia, antihipertenzív terápia, perindopril/amlodipin kombinációk

\section{One year persistence of free and fixed dose combinations of perindopril/ amlodipine}

Introduction: In management of hypertension patient adherence is one of the most important factors. In hypertension the cardiovascular risk reduction can be reached only by prolonged and effective pharmacotherapy.

Aim: To evaluate the persistence of one-year treatment of free and fixed-dose combination of perindopril/amlodipine in hypertension.

Method: Information from the National Health Insurance of Hungary prescriptions database on pharmacy claims between October 1, 2012 and September 30, 2013 was analysed. Authors identified patients who filled prescriptions for free and fixed-dose combination of perindopril/amlodipine, prescribed for the first time for hypertension. Patients have not received antihypertensive therapy with similar active substances during the one year before. Apparatus of survival analysis was used, where "survival" was the time to abandon the medication. As it was available to month precision, discrete time survival analysis was applied.

Results: 109,248 patients met the inclusion criteria. Combination antihypertensive therapy with perindopril/amlodipine was started with a free or a fixed-dose combination of these agents in 19,365 and 89,883 patients, respectively. One year persistence rate in patients taking perindopril/amlodipine as a free combination was $27.15 \%$, whereas it was 
$46.89 \%$ in those on the fixed-dose combination. Mean duration of persistence was 177.6 days in patients on the perindopril/amlodipine free, whereas 245.7 days on fixed-dose combination. Actual rate of discontinuation was approximately twice higher with the treatment of free, compared with the use of the fixed-dose combination (hazard ratio $=1.94[95 \% \mathrm{CI}: 1.91-1.98], \mathrm{p}<0.001)$.

Keywords: adherence, persistence, antihypertensive therapy, perindopril/amlodipine combinations

Simonyi G, Ferenci T, Medvegy M, Gasparics R, Finta E. [One year persistence of free and fixed dose combinations of perindopril/amlodipine]. Orv Hetil. 2017; 158(36): 1421-1425.

(Beérkezett: 2017. július 11.; elfogadva: 2017. augusztus 3.)

\section{Rövidítések}

$\mathrm{ACE}=$ angiotenzinkonvertáló enzim; $\mathrm{BNO}=$ Betegségek Nemzetközi Osztályozása; CCB = kalciumcsatorna-blokkoló; $\mathrm{CI}=$ konfidenciaintervallum; ESC = European Society of Cardiology; ESH = European Society of Hypertension; HCT = hidroklorotiazid; HR = hazard ratio; $\mathrm{MHT}$ = Magyar Hypertonia Társaság; OEP = Országos Egészségbiztosítási Pénztár; $\mathrm{SE}=$ standard error

Magyarországon az összhalálozás mintegy 50\%-a hátterében a keringésrendszer különböző betegségei állnak, miközben a nők korai ( 65 éves kor előtti) halálozásának 24\%-áért, míg a férfiaknál ennek mintegy $32 \%$-áért a felelősek. 2016-ban minden negyedik, 65 éves életkor előtt bekövetkező halálozás, azaz mintegy 7600 haláleset - a szükséges és megfelelő időben igénybe vett beavatkozással - elkerülhető lett volna Magyarországon. Mindezeken belül a hypertonia a második legnagyobb veszteséget okozó egészségkockázati tényező, amely a felnőtt lakosság egészségveszteségének ötödét teszi ki, és mintegy 700 milliárd forintnyi kiadást jelentett 2010ben. Az ischaemiás szívbetegség, a szívelégtelenség és a stroke hátterében kiemelkedő szerepet játszik a magasvérnyomás-betegség jelenléte. Háziorvosi adatok szerint a magasvérnyomás-betegséggel nyilvántartottak részaránya férfiakban és nőkben is fokozatosan emelkedett az elmúlt 15 éves időszakban $[1,2]$.

A magasvérnyomás-betegség kezelésekor a vérnyomáscélértékek elérése alapvető fontosságú a kedvezőtlen cardiovascularis szövődmények elkerülése érdekében. Kiss István és mtsai egy nemrég megjelent publikációjukban közölték, hogy hazánkban a férfiak mintegy 40\%-a, míg a nők körülbelül 44\%-a éri el a vérnyomáscélértékeket, miközben ezt a hypertonia mellett jelen lévő betegségek és állapotok is jelentősen befolyásolhatják [3].

\section{Célkitüzés}

Korábbi vizsgálatainkban már tanulmányoztuk a ramipril/amlodipin szabad és fix kombinációk, illetve a ramipril/amlodipin vs. ramipril/HCT, illetve lisinopril/ amlodipin fix kombinációk terápiahüségét. Jelen mun- kánkban egy másik ACE-gátlónak, a perindoprilnek az amlodipinnel alkotott szabad és fix kombinációinak egyéves terápiahűségét elemezzük.

\section{Betegek és módszer}

Retrospektív vizsgálatunkban az Országos Egészségbiztosítási Pénztár (OEP) adatbázisából azokat a betegeket emeltük ki, akik a 2012. október 1. és 2013. szeptember 30. közötti időszakban hypertonia indikációval (BNO: $\mathrm{I} 10 \mathrm{H} 0)$ első alkalommal váltottak ki bármely perindopril és amlodipin szabad, illetve perindopril és amlodipin fix kombinációt (bármilyen dóziskombinációban). E betegcsoportból kiválasztottuk azokat, akik a megelőző egy évben e készítmények receptjeit nem váltották ki. A receptkiváltásokat minden beteg esetében 14 hónapig, legkésőbb 2014. november 30-ig követtük. Nem kerültek bele az elemzésbe a követési időszak alatt elhunyt betegek. Hatvannapos gyógyszerkihagyást tolerálva (graceperiódus) azt tanulmányoztuk, hogy a fenti antihipertenzív terápiákban részesült betegek mekkora hányada maradt az adott szabad vagy fix kombináción a vizsgált periódus során. Az adatok - azaz a még terápián lévő betegek száma - 30 napos időközönként voltak elérhetőek.

A perindopril/amlodipin szabad és fix kombinációk perzisztenciamodellezésére a túlélésanalízis klasszikus eszköztárát alkalmaztuk, ahol a „túlélési idő” a gyógyszer szedésének kezdetétól egészen annak abbahagyásáig eltelt idő volt. Vizsgálatunkban az egyetlen magyarázó változó a gyógyszer-kombináció típusa (szabad vagy fix) volt. A gyógyszerperzisztencia-adatok 30 napos frekvenciával voltak elérhetők, ezért diszkrét idejű túlélést becsültünk és ábrázoltuk az idő függvényében. A modellezéshez komplementer log-log link függvényt használó általánosított lineáris modellt becsültünk, amely a jól ismert (folytonos idejű) túléléselemzés bevált diszkrét idejû megfelelője $[4,5]$. A gyógyszerek között a hazárd proporcionalitását úgy ellenőriztük, hogy hozzáadtuk a modellhez a gyógyszer és az eltelt idő interakcióját, majd összehasonlítottuk ennek a - szaturált - modellnek az illeszkedését az eredeti modellével. Amennyiben a non- 
proporcionalitás nem volt jelentős, úgy meghatároztuk a gyógyszerszedés abbahagyásának hazárdját (HR) is, a referenciaként használt perindopril/amlodipin fix kombinációhoz viszonyítva. Mindezek mellett kiszámoltuk mindkét kombináció szedésének 12 hónapra korlátozott átlagos túlélési idejét is [6].

\section{Eredmények}

A bevonási kritériumoknak mindösszesen 109248 beteg felelt meg. A 2012. október 1. és 2013. szeptember 30. között tartó bevonási időszakban e betegek közül 19365 kezdett perindopril/amlodipin szabad, míg 89883 beteg perindopril/amlodipin fix kombinációt.

A perindopril/amlodipin szabad kombinációt kezdőknél a 30. napra 90\%-ra, míg a harmadik hónapra 52,89\%ra csökkent a perzisztencia. Fél év elteltével a betegeknek csak 37,62\%-a volt még e terápián, azaz a betegek mintegy kétharmada elhagyta a perindopril/amlodipin szabad kombináció szedését. Ezt követően a gyógyszert szedők lemorzsolódásának üteme csökkent (fél év alatt mintegy $10 \%$ ), ami azt jelentette, hogy az első év végére a betegek $27,15 \%$-a szedte a perindopril/amlodipin szabad kombinációt (1. ábra).

A perindopril/amlodipin fix kombináció perzisztenciája gyakorlatilag nem változott $(99,99 \%)$ az első hónap végére. A harmadik hónapra a perindopril/amlodipin fix kombinációt szedők aránya 23,68\%-os csökkenéssel 76,32\%-ra mérséklődött. A gyógyszerelhagyás üteme a második három hónapos periódusban lényegesen csökkent $(-17,31 \%)$, amely 59,01\%-os féléves perzisztenciát jelentett. A második fél évben tovább mérséklődött a gyógyszert elhagyók aránya $(-12,12 \%)$, amelynek eredményeként az egyéves perzisztencia 46,89\%-nak adódott. Mindez azt jelentette, hogy a perindopril/amlodipin fix kombináció mintegy 20 százalékpontnyi perzisztenciaelőnnyel rendelkezett a szabad kombinációhoz képest.

A 360 napra korlátozott intervallumból számolt átlagos perzisztenciaidő 177,6 (SE: 0,93) nap volt a perindopril/amlodipin szabad, míg 245,7 (SE: 0,423) nap volt a perindopril/amlodipin fix kombinációt szedőknél.

A diszkrét túléléselemzési modell eredményei szerint a nonproporcionalitás mindössze 1,24\%-os lett (ennyi a proporcionális és a szaturált modell devianciái közti különbség, relatíve a proporcionális nulldevianciájához képest), ezért alkalmazhattuk a proporcionális modellt és ennek révén a HR-t. Eredményeink az igazolták, hogy a perindopril/amlodipin szabad kombináció abbahagyásának hazárdja a perindopril/amlodipin fix kombinációhoz képest mintegy kétszeres volt ( $\mathrm{HR}=1,94$ [95\% CI: 1,91-1,98], p<0,001).

\section{Megbeszélés}

A hazai (MHT) és az európai (ESC/ESH) hypertoniairányelvek szerint az ACE-gátló és a kalciumcsatornablokkoló kombinációk ajánlott gyógyszer-kombinációk-

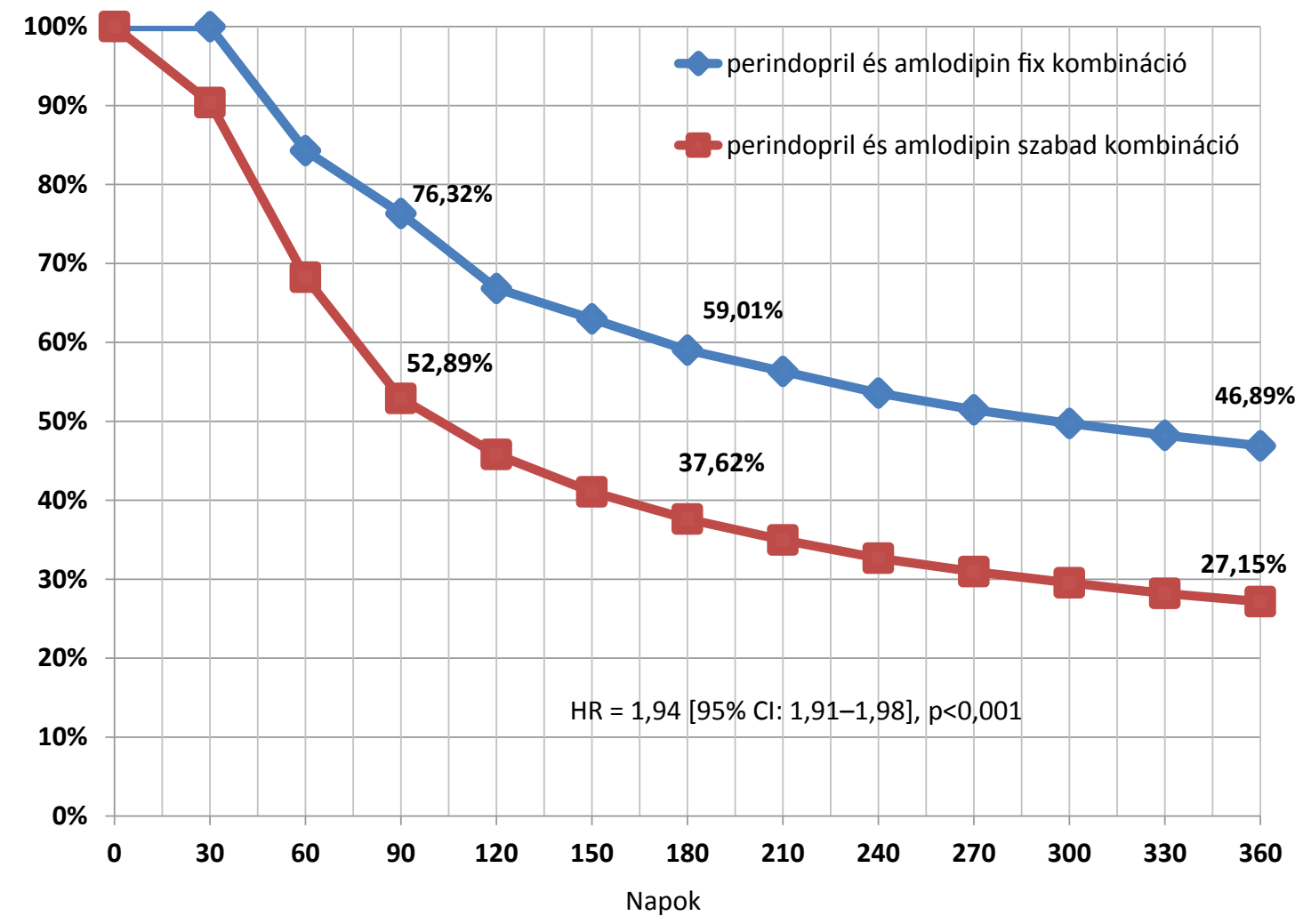

1. ábra

| A perindopril és az amlodipin szabad és fix kombinációinak egyéves perzisztenciája 
ként szerepelnek, ugyanakkor kihangsúlyozzák a fix gyógyszer-kombinációk előnyeit a terápiahúség javítása szempontjából $[7,8]$. Mindezek mellett a célvérnyomást jelentősen meghaladó betegeknél vagy nagy cardiovascularis kockázattal rendelkezőkben mindjárt két hatóanyag kombinációjával (előnybe helyezve a fix gyógyszer-kombinációkat) indíthatjuk az antihipertenzív kezelést.

Munkacsoportunk egy korábbi dolgozatában a ramipril/amlodipin szabad és a ramipril/amlodipin fix kombinációinak perzisztenciáját elemezte [9]. E tanulmányunkban több mint 30000 beteg gyógyszerszedési szokásait vizsgálva 20 százalékpontos különbséget igazoltunk a fix kombináció javára. A ramipril és az amlodipin szabad kombináció egyéves terápiahüsége 34\%, míg a fix kombinációt szedőknél $54 \%$ volt. A szabad kombináció adásakor mintegy kétszeres volt a gyógyszerelhagyás hazárdja a fix kombinációhoz képest $(\mathrm{HR}=1,94$, $\mathrm{p}<0,001)$. A perindopril/amlodipin fix kombináció javára - a szabad kombinációhoz képest - ehhez hasonló (mintegy 20 százalékpontos) perzisztenciaelőnyt találtunk mostani vizsgálatunkban. Bár "head-to-head" elemzést még nem végeztünk, de annyi megállapítható, hogy a ramipril/amlodipin fix kombináció egyéves perzisztenciája mintegy 7 százalékpontos előnnyel rendelkezik a perindopril/amlodipin fix kombinációhoz hasonlítva. Megjegyzendő az is, hogy e két ACE-gátló/ amlodipin szabad és fix kombináció elhagyásának hazárdja lényegében megegyezett $(\mathrm{HR}=1,94)$, ami azt mutatja, hogy mindkét esetben érdemes a hatóanyagok fix kombinációjára áttérni.

Egy következő vizsgálatunkban, ahol két ACE-gátló/ CCB fix kombináció perzisztenciáját elemeztük, a lisinopril/amlodipin fix kombináció egyéves terápiahüsége 36\%-os volt, ami azt jelentette, hogy mintegy 18 százalékponttal lett alacsonyabb a ramipril/amlodipin fix kombinációhoz képest [10]. Egy másik hazai vizsgálatunkban egy korszerü ACE-gátló/kalciumcsatornablokkoló és egy ACE-gátló/hidroklorotiazid (HCT) fix kombináció egyéves perzisztenciáját vettük górcső alá. E vizsgálatunkban a több mint 39000 beteg követése alatt a ramipril/HCT fix kombináció egyéves terápiahűségét 29\%-nak találtuk, míg a ramipril/amlodipin fix kombináció perzisztenciája a korábbiaknak megfelelően 54\% volt [11]. Eredményünk szerint a ramiprilalapú fix kombinációk közül a ramipril/amlodipin fix kombináció 25 százalékponttal - szignifikánsan - magasabb terápiahüséggel rendelkezett, és ennek megfelelően a ramipril/ HCT elhagyásának kockázata - a ramipril/amlodipin fix kombinációhoz képest - több mint kétszeres volt (HR: $2,318, \mathrm{p}<0,001)$.

Nemzetközi adatok szerint az antihipertenzív készítmények szabad és fix kombinációinak terápiahûsége között 20 százalékpontos különbség mutatkozik a fix kombinációk javára [12]. Jelen dolgozatunkban közölt és a korábbi eredményeink alapján hasonló tapasztalatokról számolhatunk be, miszerint a fix kombinációk terápiahú- sége 20 százalékpontos előnnyel rendelkezik a szabad kombinációkkal szemben. Korábbi vizsgálataink viszont azt is igazolták, hogy lényeges különbségek lehetnek a fix kombinációk egyéves perzisztenciája között is (lásd előbb). Jelen vizsgálatunk eredményét ugyanakkor nem tudjuk nemzetközi adatokhoz hasonlítani, mivel a perindopril/amlodipin szabad és fix kombinációinak egyéves perzisztenciáját más szerzők nem vizsgálták.

\section{Következtetések}

A retrospektív - az OEP gyógyszerkiváltási adatbázisára támaszkodó - vizsgálatunkban a perindopril/amlodipin szabad és fix kombinációinak egyéves terápiahűségét elemeztük. Korábbi, hazai vizsgálatainkhoz hasonlóan (ramipril/amlodipin) azt tapasztaltuk, hogy a szabad kombinációhoz képest a fix kombináció egyéves terápiahüsége a perindopril/amlodipin esetében is mintegy 20 százalékponttal haladja meg a szabad kombinációét. Ugyanakkor a ramipril/amlodipin fix kombináció terápiahûsége - egy hasonló időszakban - magasabbnak bizonyult a perindopril/amlodipin fix kombinációval összevetve. Mindezek mellett a ramipril/HCT és a lisinopril/amlodipin fix kombinációk egyéves perzisztenciája alulmaradt a perindopril/amlodipin fix kombinációval szemben.

Az antihipertenzív terápia során a cardiovascularis szövődmények elkerülése vagy ezek kockázatának csökkentése érdekében folyamatos és a vérnyomás-célértékeket elérő kezelésre szorul a beteg. Ebben a folyamatban a hatékony készítmények megfelelő dózisban történő alkalmazása, szükség eseten ezeknek - az irányelveknek megfelelő - kombinálása mellett a terápiahúség is alapvetően fontos $[7,8]$.

Véleményünk szerint a hazai gyógyszerszedési gyakorlat eredményeit tükröző vizsgálatainkat is érdemes számításba venni az antihipertenzív készítmények kiválasztásánál. Mindezek mellett törekednünk kell a nemzetközi összehasonlításban alacsony betegadherencia növelésére is.

\section{Limitációk}

- Vizsgálatunkban az OEP adatbázisának retrospektív analízisét végeztük, amelyben nem lehetett figyelembe venni a primer nonadherenciát, amely befolyásolja a teljes adherenciát. Azt értékeltük, hogy a felírt (és legalább egyszer kiváltott) gyógyszereket a beteg az előírt adagban és gyakorisággal váltotta-e ki.

- A perzisztenciaadatokat nem tudtuk a vizsgálatba belépés - első vénykiváltás - időpontja szerint megbontani, mivel adatbázisunkban csak összesítve volt elérhető az utánkövetési idő. (Tehát ugyanúgy az egyéves perzisztenciába tartozott az, aki 2012. október 1-jétől 2013. szeptember 30 -ig volt perzisztens és az, aki 2013. szeptember 30-tól 2014. szeptember 30-ig.) Emiatt a vizsgálati periódus alatti esetleges, perzisz- 
tenciát befolyásoló tényezőkben történt változásokat nem tudtuk vizsgálni.

- Vizsgálatunk legfontosabb módszertani limitációja, hogy nem állt rendelkezésünkre adat a potenciális confounderekról, azaz azokról a változókról, amelyek egyszerre befolyásolhatják mind a gyógyszerrendelést, mind az adherenciát (például nem, életkor, szocioökonómiai státus, betegségsúlyosság).

Anyagi támogatás: A szerzők anyagi támogatásban nem részesültek.

Szerzôi munkamegosztás: S. G.: A vizsgálat hipotézisének kidolgozása, az adatgyưjtés megtervezése, a kézirat megszövegezése. F. T.: A vizsgálat adatainak statisztikai feldolgozása, az ehhez kapcsolódó módszerek ismertetése, a kézirat szövegezése. M. M., G. R., F. E.: A vizsgálat hipotézisének kidolgozása, a kézirat megszövegezése. A cikk végleges változatát valamennyi szerző elolvasta és jóváhagyta.

Érdekeltségek: A szerzőknek nincsenek érdekeltségeik.

\section{Irodalom}

[1] Kovács K, Tóth G. State of health. In: Monostori J, Öri P, Spéder Zs. (eds.) Demographic portrait 2015. [Egészségi állapot. In: Monostori J, Öszi, P, Spéder Zs. (szerk.) Demográfiai portré 2015.] Központi Statisztikai Hivatal, Népességtudományi Kutatóintézet, Budapest, 2015; pp. 95-114. [Hungarian]

[2] Vitrai J, Varsányi P. (eds.) Information for decrease of health loss in Hungary. [Információk a hazai egészségveszteségek csökkentéséhez.] Nemzeti Egészségfejlesztési Intézet, Budapest, 2015. Available from: http://www.egeszseg.hu/szakmai_oldalak/ assets/files/news/egeszsegjelentes-2015.pdf [accessed: July 7 2017]. [Hungarian]

[3] Kiss I, Paksy A, Kékes E, et al. Efficient, cardiovascular risk-dependent therapy of patients with hypertension according to the data from database of the Hungarian Hypertension Registry.
[A hypertoniás betegek cardiovasculariskockázat-függő hatékony terápiája a Magyar Hypertonia Regiszter adatai alapján.] Hypertonia és Nephrologia 2017; 21(Suppl 1): S11-S18. [Hungarian]

[4] Singer JD, Willett JB. Applied longitudinal data analysis: Modeling change and event occurrence. Oxford University Press, New York, 2003.

[5] Mills M. Introducing survival and event history analysis. Sage Publications, London, 2011.

[6] Willett JB, Singer JD. Investigating onset, cessation, relapse, and recovery: why you should, and how you can, use discrete-time survival analysis to examine event occurrence. J Consult Clin Psychol. 1993; 61: 952-965.

[7] Mancia G, Fagard R, Narkiewicz K, et al. 2013 ESH/ESC Guidelines for the management of arterial hypertension: The Task Force for the Management of Arterial Hypertension of the European Society of Hypertension (ESH) and of the European Society of Cardiology (ESC). Eur Heart J. 2013; 34: 21592219.

[8] Kiss I. (ed) Professional and organisational guidelines for the treatment of hypertension (Guideline of the Hungarian Society of Hypertension 2015). [A hypertoniabetegség ellátása (Az MHT szakmai irányelve 2015).] Hypertonia és Nephrologia 2015; 19(Suppl. 1): 1-38. [Hungarian]

[9] Simonyi G, Ferenci T. Persistence on treatment with the fixed combination of ramipril and amlodipine. [A ramipril/amlodipin fix kombináció perzisztenciája.] Orv Hetil. 2014; 155: 18821888. [Hungarian]

[10] Simonyi G, Ferenci T. Ramipril plus amlodipine and lisinopril plus amlodipine fixed dose combinations and patient's adherence. [A ramipril/amlodipin és a lisinopril/amlodipin fix kombinációk a terápiahűség tükrében.] Orv Hetil. 2016; 157: 30-34. [Hungarian]

[11] Simonyi G, Ferenci T, Alföldi S, et al. Ramipril + amlodipine and ramipril + hydrochlorothiazide fixed-dose combinations in relation to patient adherence. J Int Med Res. 2016; 44: 1087-1091.

[12] Dezii, CM. A retrospective study of persistence with single-pill combination therapy vs. concurrent two-pill therapy in patients with hypertension. Manag. Care 2000; 9(9 Suppl): S2-S6.

(Simonyi Gábor dr., Budapest, Tétényi út 12-16., 1115 e-mail: bmbel3@gmail.com)

\section{BŐRGYÓGYÁSZOK FIGYELMÉBE!}

Szentendre föútján, bevezetett, ÁNTSZ engedéllyel rendelkező orvosi rendelöben, bőrgyógyászati rendelésre teljesen felszerelve, rendelési idő kiadó.

A rendelő utcai bejáratú, betegparkolóval rendelkezik.

Kiterjedt pacientúra!

Heti rendelés feltöltése megoldott, csak rendelni kell!

Érdeklődni: 06-20-44-44-860 